\title{
PENERAPAN MEDIA SIMULASI PhET UNTUK MENINGKATKAN AKTIVITAS SISWA PADA FASE PENGUMPULAN DATA PERCOBAAN DAN MENGOLAH SERTA MERUMUSKAN SUATU PENJELASAN DALAM MODEL PEMBELAJARAN INQUIRY TRAINING DI SMA NEGERI 5 TAKENGON
}

\author{
Komyadi dan Derlina \\ Jurusan Fisika Pascasarjana Universitas Negeri Medan \\ Email: komyadi80@gmail.com
}

\begin{abstract}
Abstrak. Penelitian ini bertujuan untuk meningkatkan keterampilan proses sains pada aspek skill dan kognitif dengan penerapan model pembelajaran inquiry training menggunakan media simulasi PhET. Metode penelitian yang digunakan adalah Penelitian Tindakan Kelas (PTK) yang terdiri dari dua siklus dengan masing-masing siklus memiliki empat tahapan kegiatan yaitu perencanaan, tindakan, observasi dan refleksi. Penelitian ini dilakukan di SMA Negeri 5 Takengon kelas XI.IPA-1 yang terdiri dari 25 siswa pada semester genap tahun pelajaran 2013/2014. Teknik pengumpulan data yang digunakan adalah catatan lapangan, tes, observasi, dan angket. Dari hasil penelitian diperoleh nilai rata-rata keterampilan proses sains siswa (aspek skill) pada siklus I adalah 66,18 dengan ketuntasan klasikal 36\% dan pada siklus II 77,77 dengan ketuntasan klasikal 92\% dengan $\mathrm{N}$-gain 47,81\% (sedang). Nilai rata-rata keterampilan proses sains (aspek kognitif) siswa pada siklus I adalah 61,87 dengan ketuntasan klasikal 48\%, sedangkan pada siklus II 78,15 dan ketuntasan klasikal 88\% dengan $\mathrm{N}$-gain 69\% (sedang). Hasil angket respon siswa terhadap pembelajaran pada siklus I positif dan pada siklus II sangat positif. Dengan demikian penerapan model pembelajaran inquiry training menggunakan media simulasi PhET dapat meningkatkan keterampilan proses sains (aspek skill dan kognitif).
\end{abstract}

Kata kunci: keterampilan proses sains, inquiry training, simulasi PhET

\section{THE APPLICATION OF THE SIMULATION PHET MEDIA TO INCREASE THE ACTIVITY OF STUDENTS ON DATA COLLECTION PHASE OF THE EXPERIMENT AND TO PROCESS AND FORMULATED AN EXPLANATION IN THE MODEL OF LEARNING INQUIRY TRAINING IN HIGH SCHOOLS 5 TAKENGON}

\author{
Komyadi and Derlina \\ Physics Education Program, Graduate State University of Medan \\ Email: komyadi80@gmail.com
}

\begin{abstract}
The aim of this study were to improve the science process skills (skill and cognitive aspects) by implementation of inquiry training learning model using PhET simulation media. The method used Classroom Action Research (CAR), which consists of two cycles with each cycle has four phases: planning activity, action, observation and reflection. This research was conducted at SMAN 5 Takengon XI.IPA-1 class consisting of 25
\end{abstract}


students in the second semester of academic year 2013/2014. Data collection techniques used field notes, tests, observations, and questionnaires. The results were obtained an average value of students' science process skills (skill aspects) in the first cycle was 66.18 with classical completeness $36 \%$ and the second cycle 77.77 and classical completeness $92 \%$ with $\mathrm{N}$ gain $47.81 \%$ (moderate). The average value of science process skills (cognitive aspect) of students in the first cycle was 61.87 with classical completeness $48 \%$, while in the second cycle 78.15 and classical completeness $88 \%$ with $\mathrm{N}$-gain of $69 \%$ (moderate). The results of student questionnaire responses to a positive learning in the first cycle and the second cycle is very positive. Thus the application of inquiry training learning model using PhET simulation media to increase the science process skills (skills and cognitive aspects).

Keywords: science process skills, inquiry training, PhET simulations

\section{PENDAHULUAN}

Tujuan belajar ilmu pengetahuan (science) agar siswa dapat memiliki penguasaan konsep, keterampilan proses dan sikap, hal ini berlaku secara universal. Kegiatan pembelajaran harus dirancang atau dipilih sehingga dapat berhubungan dengan kebutuhan dan pengalaman sehari-hari siswa, untuk menumbuhkan rasa ingin tahu dengan melibatkan mereka aktif dalam pembelajaran dan berusaha untuk mengatasi permasalahan yang terjadi pada kehidupan nyata.

Untuk mencapai tujuan pendidikan sains tersebut, berbagai kebijakan pada bidang pendidikan telah diambil dan dilaksanakan oleh pemerintah antara lain desentralisasi, standardisasi, peningkatan anggaran, perubahan kurikulum dan lain sebagainya. Penyempurnaan mind set pada kurikulum 2013 juga berlaku pada pelajaran fisika. Di Sekolah Menengah Atas (SMA) pelajaran fisika termasuk pada kelompok peminatan matematika dan sains (Permendikbud. No. 69, 2013). Pelajaran fisika dipandang penting untuk diajarkan sebagai mata pelajaran tersendiri dengan beberapa pertimbangan. Pertama, selain memberikan bekal ilmu kepada peserta didik, mata pelajaran fisika dimaksudkan sebagai wahana untuk menumbuhkan kemampuan berpikir sehingga berguna untuk menyelesaikan masalah di dalam kehidupan sehari-hari. Kedua, mata pelajaran fisika perlu diajarkan untuk tujuan yang lebih khusus yaitu membekali peserta didik pengetahuan, pemahaman dan sejumlah kemampuan yang dipersyaratkan untuk memasuki jenjang pendidikan yang lebih tinggi serta mengembangkan ilmu dan teknologi. Pembelajaran fisika dilaksanakan secara inkuiri ilmiah untuk menumbuhkan kemampuan berpikir, bekerja dan bersikap ilmiah serta berkomunikasi sebagai salah satu aspek penting kecakapan hidup (Depdiknas, 2006).

Sudah menjadi tugas guru untuk melakukan perbaikan atau memilih model pembelajaran yang sesuai dengan memadukan strategi dan media pembelajaran yang akan digunakan dalam proses belajar mengajar. Salah satu model pembelajaran yang dapat melibatkan siswa aktif memproses informasi dan bekerja ilmiah adalah model pembelajaran inquiry training. Model pembelajaran ini terdiri dari 5 fase yaitu: (1) menghadapkan pada permasalahan, (2) pengumpulan data verifikasi, (3) pengumpulan data percobaan, (4) mengolah, merumuskan dan penjelasan, (5) Analisis proses inkuiri (Joyce, dkk. 2009).

Keterampilan proses sains adalah serangkaian tindakan yang kontinyu yang dihasilkan dari pengalaman, sehingga terjadi perubahan yang berlangsung secara internal dan biasanya dapat ditunjukkan secara eksternal (Yadav dan Mishra, 2013). Keterampilan proses kadang- 
kadang disebut sebagai 'investigasi' atau keterampilan inkuiri, penggunaan kata keterampilan proses dikarenakan keterampilan ini diperoleh melalui suatu proses yang panjang, yaitu proses berinteraksi dengan alat dan bahan kemudian dilakukan pengolahan data sehingga diperoleh informasi. Keterampilan proses penting sekali digunakan karena keterampilan ini merupakan pusat penalaran dan pengembangan pemahaman (Harlen dan Qualter, 2004). Keterampilan proses menurut Harlen \& Elstgeest (1992) terdiri dari: mengamati, mengajukan pertanyaan, merumuskan hipotesis, memprediksi, menemukan pola dan hubungan, berkomunikasi secara efektif, merencanakan dan melakukan penyelidikan, mengukur dan menghitung.

Berdasarkan hasil observasi pada saat pembelajaran dengan model pembelajaran inquiry training yang peneliti lakukan di SMA Negeri 5 Takengon, terdapat beberapa kendala dalam pelaksanaan pembelajaran, kendala tersebut terlihat ketika siswa akan mulai melakukan pengujian hipotesis untuk mengumpulkan data melalui eksperimen (fase ketiga), mengolah data, serta merumuskan penjelasan (fase keempat). Pada fase ketiga seharusnya siswa dapat memilih alat dan bahan secara tepat dalam melakukan percobaan, mengidentifikasi variabel pengubah, variabel kontrol variabel yang di ukur dengan tepat, dan menentukan langkah yang dilakukan dalam penyelidikan.

Untuk mengatasi permasalahan rendahnya keterampilan proses sains siswa perlu dicari solusi agar model pembelajaran inquiry training dapat berlangsung dengan baik. Salah satu cara untuk mengatasi singkatnya waktu dalam pelaksanaan percobaan model pembelajaran inquiry training perlu adanya media pembelajaran yang dapat menunjang dalam kegiatan percobaan (eksplorasi), media pembelajaran yang digunakan hendaknya media simulasi yang dapat memvisualisasikan fenomena yang abstrak dan mikroskopik yang tidak dapat di pahami melalui laboratorium nyata, sehingga siswa dapat menemukan fakta-fakta melalui simulasi-simulasi dengan komputer. Salah satu media simulasi yang dapat digunakan adalah simulasi PhET. Dengan menggunakan simulasi ini siswa layaknya dapat melakukan kegiatankegiatan untuk mendapatkan data dan fakta seperti pada laboratorium rill, sehingga dengan data dan fakta tersebut peserta didik dapat mengambil kesimpulan tentang konsep-konsep fisika (Baser \& Durmus, 2010).

Simulasi PhET tersedia di situs resmi PhET (http://phet.colorado.edu) yang menyediakan berbagai simulasi dalam pelajaran sains yang dapat digunakan dengan gratis baik dengan cara online maupun offline. Simulasi PhET sangat interaktif dimana pada simulasi ini siswa dapat menggunakan secara mandiri ataupun di bantu oleh guru dalam penggunaannya (McKagan, 2008, Perkins, dkk, 2013). Tujuan yang ingin dicapai dalam penelitian ini adalah meningkatkan keterampilan proses sains melalui penerapan model pembelajaran inquiry training menggunakan media simulasi PhET pada siswa kelas XI. IPA semester genap pada materi fluida statis dan fluida dinamis.

\section{METODE PENELITIAN}

Penelitian ini dilaksanakan di SMA Negeri 5 Takengon Kabupaten Aceh Tengah pada bulan Maret s/d Mei 2014. Subjek penelitian adalah siswa kelas XI.IPA-1 yang berjumlah 25 siswa. Penelitian ini adalah Penelitian Tindakan Kelas (PTK) yang menjadi fokus dalam penelitian ini adalah Keterampilan Proses Sains (KPS) pada aspek skill dan kognitif. Penelitian ini dilakukan pada dua siklus pada setiap siklus membahas materi yang berbeda, setiap siklus terdiri dari perencanaan, tindakan, pengamatan dan refleksi. Kegiatan siklus ini sampai indikator keberhasilan tercapai yaitu keterlaksanaan pembelajaran pada kategori baik, nilai rata-rata keterampilan proses sains (aspek skill dan kognitif) lebih besar 70, ketuntasan klasikal lebih besar $85 \%$, dan respon siswa terhadap pembelajaran lebih besar dari $70 \%$.

Kegiatan penelitian ini dibagi menjadi dua bagian, yaitu (1) Pra pelaksanaan penelitian dan (2) Pelaksanaan penelitian. Kegiatan Pra pelaksanaan penelitian meliputi: menyusun RPP 
model pembelajaran inquiry training menggunakan media simulasi PhET pada sub pokok bahasan fluida statis dan fluida dinamis, Lembar Kerja Siswa (LKS) dan perangkat evaluasi. Perangkat evaluasi yang digunakan adalah instrumen tes dan lembar observasi Keterampilan Proses Sains (KPS) yang kemudian divalidasi.

Sebelum penerapan model pembelajaran inquiry training menggunakan media simulasi PhET dilakukan pretest KPS untuk siklus I dan II. Penerapan model pembelajaran inquiry training menggunakan media simulasi PhET terdiri dari 5 fase. Fase pertama dimulai dengan memberikan permasalahan kepada siswa, fase kedua siswa melakukan verifikasi data dengan mengajukan pertanyaan yang dapat dijawab "ya" dan "tidak", fase ketiga siswa melakukan pengumpulan data melalaui percobaan dengan menggunakan peralatan rill dan media simulasi PhET menggunakan laptop, fase keempat siswa mengolah dan merumuskan penjelasan dari hasil data percobaan, dan fase kelima dilakukan analisis proses inkuiri baik yang menyangkut materi pembelajaran ataupun proses inkuiri. Pada saat dilakukan pembelajaran dilakukan observasi dengan menggunakan lembar observasi KPS untuk mengetahui KPS siswa pada aspek skill, pada setiap akhir siklus dilakukan postes dan diberikan angket untuk mengetahui respon siswa terhadap pembelajaran.

Untuk mengetahui peningkatan keterampilan proses sains siswa pada setiap siklus digunakan gain ternormalisasi $<\mathrm{g}>$ dengan rumus:

Tabel 1. Rekapitulasi keterlaksanaan pembelajaran pada siklus I dan siklus II

\begin{tabular}{|c|c|c|c|c|c|c|}
\hline \multirow[t]{2}{*}{ Tindakan } & \multicolumn{3}{|c|}{ Pertemuan } & \multirow[t]{2}{*}{ Rata-Rata } & \multirow[t]{2}{*}{ Kategori } & \multirow[t]{2}{*}{$N$-gain } \\
\hline & 1 & 2 & 3 & & & \\
\hline Siklus I & $54,67 \%$ & $60,00 \%$ & $78,67 \%$ & $64,44 \%$ & Cukup & $61,25 \%$ \\
\hline Siklus II & $81,33 \%$ & $85,33 \%$ & $92,00 \%$ & $86,22 \%$ & Sangat Baik & (sedang) \\
\hline
\end{tabular}

Data keterlaksanaan pembelajaran pada setiap pertemuan mengalami peningkatan, ratarata pada siklus I yaitu $64,44 \%$ (cukup) dan pada siklus II $86,22 \%$ (sangat baik) dengan $N$ gain $61,25 \%$. Pada saat dilakukan tindakan penerapan model pembelajaran inquiry training tabel 2.

$$
\langle g\rangle=\frac{\langle \% \text { postes }\rangle-\langle \% \text { pretes }\rangle}{100 \%-\langle \% \text { Pretes }\rangle} \text { (Hake, 2007) }
$$

Kriteria peningkatan (gain ternormalisasi) rata-rata apabila nilai gain lebih besar dari 0,7 maka tergolong dalam kategori tinggi, gain yang berkisar antara 0,3-0,7 maka tergolong sedang, dan gain yang lebih kecil dari 0,3 maka tergolong rendah.

Sebagai indikator keberhasilan penelitian adalah apabila keterlaksanaan model pembelajaran inquiry training menggunakan media simulasi PhET lebih besar dari 85\%, nilai ratarata keterampilan proses sains siswa (aspek skill dan kognitif) telah mencapai nilai KKM (70) secara individual dan mencapai ketuntasan klasikal 85\% dan respon siswa terhapa pembelajaran pada kategori positif (70\%-85\%).

\section{HASIL PENELITIAN DAN PEMBAHASAN Hasil Penelitian}

Penerapan model pembelajaran inquiry training menggunakan media simulasi PhET dilaksanakan dalam dua siklus. Materi pembelajaran pada siklus I yaitu fluida statis sedangkan pada siklus II fluida dinamis. Setiap siklus terdiri dari 3 pertemuan, pada setiap pertemuan dilakukan observasi untuk memperoleh nilai KPS siswa (aspek skill) dan persentase keterlaksanaan pembelajaran, observasi ini dilakukan oleh observer dengan menggunakan lembar observasi.

Rekapitulasi keterlaksanaan pembelajaran pada setiap pertemuan dapat dilihat pada tabel 1. observasi KPS (aspek skill) untuk memperoleh nilai KPS siswa pada aspek skill. Rekapitulasi nilai KPS pada aspek skill dapat dilihat pada 
Tabel 2. Rekapitulasi Nilai Keterampilan

Proses Sains (Aspek Skill)

\begin{tabular}{|c|c|c|c|}
\hline No & $\begin{array}{l}\text { Aspek KPS yang } \\
\text { diamati }\end{array}$ & Siklus I & Siklus II \\
\hline 1. & Mengamati & 62,78 & 78,22 \\
\hline 2. & Mengajukan pertanyaan & 58,50 & 70,50 \\
\hline 3. & Merumuskan hipotesis & 62,33 & 81,00 \\
\hline 4. & Memprediksi & 67,00 & 71,00 \\
\hline 5. & $\begin{array}{l}\text { Menemukan pola dan } \\
\text { hubungan }\end{array}$ & 57,11 & 77,11 \\
\hline 6. & $\begin{array}{l}\text { Berkomunikasi secara } \\
\text { efektif }\end{array}$ & 64,11 & 77,00 \\
\hline 7. & $\begin{array}{l}\text { Merencanakan dan } \\
\text { melakukan } \\
\text { penyelidikan }\end{array}$ & 68,50 & 69,42 \\
\hline 8. & $\begin{array}{l}\text { Mengukur dan } \\
\text { menghitung }\end{array}$ & 62,17 & 74,50 \\
\hline \multicolumn{2}{|c|}{ Nilai terendah } & 54,17 & 68,33 \\
\hline \multicolumn{2}{|c|}{ Nilai tertinggi } & 77,50 & 84,58 \\
\hline \multicolumn{2}{|c|}{ Rata-rata } & 66,18 & 77,77 \\
\hline \multicolumn{2}{|c|}{ Ketuntasan klasikal } & $36 \%$ & $92 \%$ \\
\hline
\end{tabular}

$N$-gain

$34,25 \%$

Data nilai keterampilan proses sains diperoleh dari hasil penilaian lembar observasi keterampilan proses sains yang dilakukan oleh observer. Dari data tersebut terlihat pada siklus II mengalami peningkatan keterampilan proses sains. Peningkatan keterampilan proses sains pada siklus II terjadi pada setiap komponen keterampilan proses sains. Nilai terendah meningkat dari 54,17 menjadi 68,33 , nilai ratarata meningkat dari 66,18 menjadi 77,77 dan ketuntasan klasikal dari $36 \%$ menjadi 92\%, ketuntasan klasikal ini telah sesuai dengan indikator keberhasilan yang diharapkan.

Rekapitulasi hasil tes sebelum dan sesudah diberikan tindakan (pretes-postes) dapat dilihat pada tabel 3 .

Tabel 3. Hasil Nilai Tes Keterampilan Proses Sains (Aspek Kognitif) Siklus I Dan Siklus II

\begin{tabular}{ccccc} 
Hasil Nilai Tes & \multicolumn{2}{c}{ Siklus I } & \multicolumn{2}{c}{ Siklus II } \\
Nilai tertinggi & Pretes & Postes & Pretes & Postes \\
Nilai terendah & 60,00 & 86,67 & 46,67 & 92,31 \\
Rata-rata & 13,33 & 40,00 & 13,33 & 28,00 \\
Ketuntasan klasikal & 26,93 & 61,87 & 28,00 & 78,15 \\
N-gain & $0 \%$ & $48 \%$ & $0 \%$ & $88 \%$ \\
\hline
\end{tabular}

Efektifitas tindakan yang diberikan terlihat dari peningkatan ( $\mathrm{N}$-gain) pada siklus I yaitu $47,81 \%$ (kategori sedang) sedangkan pada siklus II meningkat menjadi 69\% (kategori sedang). Ketuntasan klasikal pada siklus II juga sudah sesuai dengan indikator keberhasilan yang diharapkan.

Pada setiap akhir siklus selain diadakan postes juga diberikan angket respon siswa terhadap pembelajaran, data respon siswa terhadap pembelajaran pada siklus I dan siklus II dapat dilihat pada tabel 4.

Tabel 4. Rekapitulasi Respon Siswa Terhadap Pembelajaran Pada Siklus I Dan Siklus II

\begin{tabular}{cccc}
\hline Tindakan & Persentase & Kategori & N-gain \\
Siklus I & $78,88 \%$ & Positif & \\
Siklus II & $88,14 \%$ & Sangat & $43,92 \%$ \\
& & Positif & \\
\hline
\end{tabular}

Dari angket respon yang diberikan respon siswa terhadap pembelajaran mengalami peningkatan pada setiap siklus, pada siklus ratarata persentase respon siswa 78,88\% (positif) sedangkan pada siklus II 88,14\% (sangat positif) dengan $\mathrm{N}$-gain $43,92 \%$ (sedang).

\section{Pembahasan}

Peningkatan keterampilan proses sains (aspek skill) pada siklus II dapat terjadi karena siswa dapat bekerja secara mandiri dan aktif dalam proses pembelajaran dan sudah mulai terbiasa dalam model pembelajaran inquiry training menggunakan media simulasi PhET sehingga kegiatan dapat efektif berjalan sesuai dengan fase-fase dalam model pembelajaran inquiry training. Dengan model pembelajaran ini menekankan kepada proses keterlibatan 
Komyadi dan Derlina: Penerapan Media Simulasi PHET Untuk Meningkatkan Aktivitas Siswa Pada Fase Pengumpulan Data Percobaan dan Mengolah serta Merumuskan Suatu Penjelasan dalam Meodel Pembelajaran Inquiry Training di SMA Negeri Takengon

kannya dengan lingkungan sekitar. Model pembelajaran inquiry training dapat digunakan untuk mendorong siswa lebih aktif dan kreatif dalam melakukan penyelidikan, sehingga keterampilan proses sains siswa dapat meningkat karena dalam model pembelajaran inquiry training memiliki sintaks yang menuntun siswa untuk memiliki rasa ingin tahu terhadap suatu permasalahan yang harus dibuktikan melalui sebuah eksperimen. Pada tahap awal model pembelajaran inquiry training siswa diberikan permasalahan yang membingungkan, kebingungan ini yang membuat siswa memiliki rasa keingintahuan untuk mengajukan pertanyaan, memverifikasi data, membuat hipotesis, merencanakan dan melakukan percobaan untuk menyelesaikan permasalahan yang diberikan (Joyce, 2009). Peningkatan keterampilan proses sains ini sejalan dengan penelitian sebelumnya yaitu: Khan dan Iqbal (2011) menyimpulkan hasil penelitiannya yang menunjukkan bahwa metode pengajaran laboratorium inkuiri lebih efektif dalam mengembangkan keterampilan proses sains di kalangan siswa sekolah menengah, Ergül dkk. (2011) hasil penelitian menunjukkan bahwa penggunaan metode pengajaran berbasis inkuiri secara signifikan meningkatkan proses sains siswa pada ranah keterampilan dan sikap.

Penerapan model pembelajaran inquiry training menggunakan media simulasi PhET menjadikan pembelajaran akan lebih mudah dipahami, hal ini sesuai dengan apa yang telah diungkapkan oleh Djamarah dan Zain (2010) dan Sanjaya (2012) bahwa dengan bantuan media guru dapat menyajikan pembelajaran yang bersifat abstrak terlihat menjadi lebih konkret, dan menambah gairah serta motivasi siswa sehingga siswa akan lebih mudah memahami materi pelajaran yang disajikan. Menurut Perkins, dkk (2013) media simulasi PhET sangat tepat di untuk kegiatan eksplorasi di laboratorium untuk kelompok kecil. Hal yang sama juga disampaikan Finkelstein (2005) bahwa media simulasi PhET memiliki karakte-
Jurnal Pendidikan Fisika

p-ISSN 2252-732X

e-ISSN 2301-7651

egiatan pembelajaran yang melibatkan an interaktif, adanya umpan balik dan dengan pendekatan konstruktivis. Tarekegn (2009) dalam penelitiannya menyimpulkan bahwa dengan pembelajaran simulasi yang berpusat pada siswa (Simulations in Student Centered) dapat meningkatkan keterampilan siswa walaupun tidak menggunakan instrumen nyata, Sahin (2006) Simulasi komputer juga berguna untuk meningkatkan keterampilan merumuskan hipotesis, keterampilan interpretasi grafis dan keterampilan memprediksi.

Nilai rata-rata KPS siswa (aspek skill) pada siklus II adalah 77,77 dan jumlah siswa yang tuntas adalah 23 (92\%) orang, sehingga ketuntasan klasikal siswa telah lebih besar dari $85 \%$, hal ini berarti penerapan model pembelajaran inquiry training menggunakan media simulasi PhET sudah berhasil meningkatkan KPS siswa pada aspek skill.

Peningkatan keterampilan proses sains pada aspek kognitif pada siklus II mencapai kriteria tuntas baik secara individual maupun klasikal, karena siswa sudah merasa terbiasa dalam mengikuti kegiatan model pembelajaran inquiry training menggunakan media simulasi PhET sehingga siswa dapat mengikuti semua langkah-langkah pembelajaran yang diinstruksikan oleh guru, dengan pembelajaran inquiry training menggunakan media simulasi PhET siswa dilatih untuk menyelesaikan permasalahan yang diberikan secara mandiri melalui percobaan, sehingga siswa dapat membangun pengetahuannya melalui kegiatan mengamati, mengajukan pertanyaan, merumuskan hipotesis, merancang dan melakukan percobaan, mengolah data hasil percobaan dan melakukan diskusi terhadap hasil percobaan yang telah dilakukan. Dengan pembelajaran ini membuat siswa dapat bekerjasama dalam diskusi kelompok sehingga yang mengharuskan siswa memberikan masukan kepada siswa lain sehingga siswa yang memiliki prestasi akademik rendah lebih termotivasi dalam mempelajari materi yang kurang dimengerti. Kemampuan kognitif siswa lebih baik dikarenakan siswa terlibat langsung dalam proses menemukan 
a siswa dapat mengikuti setiap langkahpembelajaran secara mandiri. Pening-

lebih efektif, efisien dan termotivasi dalam berpikir kreatif. Hal ini sesuai dengan kerucut pengalaman belajar Edgar Dale apabila siswa belajar melalui pengalaman langsung atau dengan model simulasi yang dilakukan secara langsung siswa dapat mengingat $90 \%$ dari apa yang dipelajari melalui percobaan langsung dengan peralatan rill ataupun dengan model simulasi (Pastore, 2003).

Peningkatan KPS aspek kognitif ini sejalan dengan hasil penelitian sebelumnya yang dilakukan Pandey, et. al. (2011) dalam penelitiannya menyimpulkan bahwa model pembelajaran inquiry training efektif dapat meningkatkan prestasi akademik siswa. Dengan menggunakan media simulasi PhET dalam melakukan percobaan maka siswa akan mengkonstruksi pengetahuannya secara mandiri. Hal ini sesuai dengan kesimpulan penelitian Sahin (2006) bahwa simulasi komputer kolaboratif dapat menarik minat peserta didik dalam melengkapi pembelajaran konstruktivis, menawarkan lingkungan inkuiri dan sebagai alat bantu dalam keterampilan pemecahan masalah, hal yang sejalan diungkapkan Finkelstein (2005) dalam penelitiannya bahwa media simulasi efektif dapat meningkatkan pemahaman konsep siswa.

Peningkatan respon pembelajaran pada setiap siklus dapat terjadi karena pada siswa sudah nyaman dan terbiasa dengan pembelajaran dengan penerapan model inquiry training yang dipadukan dengan media simulasi PhET. Penerapan model pembelajaran inquiry training menggunakan media simulasi PhET memberikan kesempatan kepada siswa untuk mengkonstruksi pengetahuannya sendiri, peran guru dalam pembelajaran hanya sebagai fasilitator dan motivator. Penggunaan media simulasi dalam melakukan percobaan merupakan pengalaman baru bagi siswa sehingga lebih termotivasi dalam melakukan percobaan. Peningkatan respon dari siklus I ke siklus II dikarenakan peneliti juga terus berupaya memperbaiki kekurangan-kekurangan selama pembelajaran katan respon siswa ini sejalan dengan peningkatan keterlaksanaan pembelajaran dan keterampilan proses sains.

\section{KESIMPULAN}

Dari hasil penelitian dan pembahasan penelitian diketahui bahwa ada peningkatan: keterlaksanaan pembelajaran penerapan model pembelajaran inquiry training menggunakan media simulasi PhET dengan $N$-gain $61 \%$, peningkatan KPS aspek skill dengan $\mathrm{N}$-gain $34 \%$, Peningkatan KPS aspek kognitif dengan $N$-gain pada siklus I $47,81 \%$ dan pada siklus II $69 \%$, serta peningkatan respon siswa terhadap pembelajaran meningkat dengan $\mathrm{N}$-gain $43,92 \%$.

\section{DAFTAR PUSTAKA}

Baser, M \& Durmus, S. 2010. The Effectiveness of Computer Supported Versus Real Laboratory Inquiry Learning Environments on the Understanding of Direct Current Electricity among PreService Elementary School Teachers. Eurasia Journal of Mathematics, Science \& Technology Education. 6(1). (Online), tersedia di: http://www.ejmste.com/v6n1/ EURASIA v6n1 Baser.pdf, diakses pada 10 November 2013.

Depdiknas. 2006. Standar Isi Untuk Satuan Pendidikan Dasar dan Menengah. Jakarta: BSNP.

Djamarah, S.B dan Zain, A. 2010. Strategi Belajar Mengajar. Jakarta: Rineka Cipta.

Ergül, R, dkk. 2011. The effects of inquirybased science teaching on elementary school students' science process skills and science attitudes. Bulgarian Journal of Science and Education Policy (BJSEP), Vol. 5(1). (Online, tersedia di: http://bjsep.org/getfile.php?id=88, diakses 14 Februari 2014)

Finkelstein, N. dkk. 2005. When learning about the real world is better done virtually: A study of substituting computer simulations for laboratory equipment. Physical Review 
edu/physics/ EducationIssues/papers/CCK final.pdf, diakses 10 November 2013).

Hake, R.R. 2007. Design-Based Research in Physics Education Research: A Review" in A.E. Kelly, R.A. Lesh, \& J.Y. Baek, eds. (in press), Handbook of Design Research Methods in Mathematics, Science, and Technology Education. Erlbaum; (online, tersedia: (http://www. physics.indiana.edu/ hake/DBR-Physics3.pdf diakses 24 November 2013).

Harlen, W \& Elstgeest, J. 1992. UNESCO Source Book for Science Teaching in the Primary School", NBT, New Delhi.

Harlen, W. \& Qualter, A. 2004. The Teaching Of Science In Primary Schools (4th edn). London: David Fulton.

Joyce, B \& Weil. 2003. Model of Teaching (fifth edition). New Delhi: India. PrenticeHall.

Joyce, B, dkk. 2009. Model of Teaching: Model-Model Pengajaran. Terjemahan oleh Achmad Fawaid dan Ateilla Mirza. Yogyakarta: Pustaka Pelajar.

Khan, M. \& Iqbal, M.Z. 2011. Effect of Inquiry Lab Teaching Method on the Development of Scientific Skills Through the Teaching of Biology in Pakistan. LANGUAGE IN INDIA. Strength for Today and Bright Hope for Tomorrow Volume 11: 1 ISSN 1930-2940. (online: tersedia di: http://www.languageinindia .com/jan2011/inquirymethodpakistan. pdf, diakses 14 Februari 2014).

McKagan, S.B. dkk. 2008. Developing and Researching PhET Simulation for Teaching Quantum Mechanics. Physics Education Technology Journal.

Pandey, dkk. 2011. Effectiveness of Inquiry Training Model over Conventional zaching Method on Academic Achieveent of Science Students in India. Journal of Innovative Research in Education 1(1). Global Research Publishing. (online, tersedia di: http://www. grpjournal.org/download/Effectiveness $\%$ 20of\%20Inquiry\%20Training\%20Model $\% 20$ over $\% 20$ Conventional $\% 20$ Teaching $\% 20$ Method $\% 20$ on $\% 20$ Academic $\% 20$ Ac hievement $\% 20$ of $\% 20$ Science $\% 20$ Student s\%20in\%20India.aspx, diakses 10-112013).

Pastore, R. S. 2003. Principle of Teaching. (online tersedia di: http://teacherworld. com/potdale.html, diakses 20 November 2013).

Permendikbud No. 69. 2013. Tentang Kerangka Dasar dan Struktur Kurikulum Sekolah Menengah Atas/Madrasah Aliyah. Jakarta: BSNP.

Perkins, K, dkk. 2013. About PhET (online), tersedia di: http://phet.colorado.edu, diakses pada 25 November 2013.

Sahin, S. 2006. Computer Simulations In Science Education: Implications For Distance Education. Turkish Online Journal of Distance Education-TOJDE ISSN 1302-6488 Volume: 7 Number: 4 Article: 12. (online, tersedia di: http:// files.eric.ed.gov/fulltext/ED494379.pd f., diakses 14 Februari 2014).

Sanjaya, W. 2012. Strategi Pembelajarn Berorientasi Standar Proses Pendidikan. Jakarta: Kencana Prenada Media Group.

Yadav, B. \& Mishra, S.K. 2013. A Study of the impact Laboratory Approach on Achievement and Process Skills in Science among is standar student. International Journal of Scientific and Research Publications, Volume 3, Issue 1. (online, tersedia di: http://www.ijsrp.org/research-paper-1301/ ijsrp-p1382.pdf, diakses 14 Februari 2014) 
